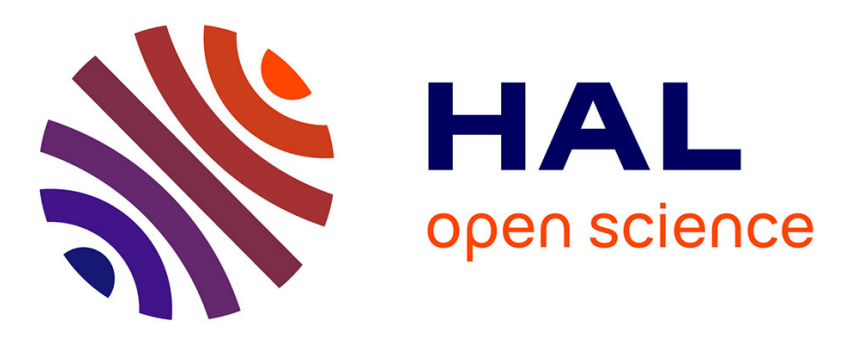

\title{
When technological discontinuities and disruptive business models challenge dominant industry logics: insights from the drugs industry
}

\author{
Valérie Sabatier, Adrienne Kennard, Vincent Mangematin
}

\section{- To cite this version:}

Valérie Sabatier, Adrienne Kennard, Vincent Mangematin. When technological discontinuities and disruptive business models challenge dominant industry logics: insights from the drugs industry. Technological Forecasting and Social Change, 2012, 79 (5), pp.949-962. 10.1016/j.techfore.2011.12.007. hal-00658727

\section{HAL Id: hal-00658727 \\ http://hal.grenoble-em.com/hal-00658727}

Submitted on 11 Jan 2012

HAL is a multi-disciplinary open access archive for the deposit and dissemination of scientific research documents, whether they are published or not. The documents may come from teaching and research institutions in France or abroad, or from public or private research centers.
L'archive ouverte pluridisciplinaire HAL, est destinée au dépôt et à la diffusion de documents scientifiques de niveau recherche, publiés ou non, émanant des établissements d'enseignement et de recherche français ou étrangers, des laboratoires publics ou privés. 


\title{
WHEN TECHNOLOGICAL DISCONTINUITIES AND DiSRUPTIVE BUSINESS MODELS CHALLENGE DOMINANT INDUSTRY LOGICS: INSIGHTS FROM THE DRUGS INDUSTRY
}

\author{
Sabatier V.,2,*, Kennard A. ${ }^{3}$, Mangematin V. ${ }^{1}$ \\ *: Corresponding author, tel.: +33.476.706.528 \\ 1 : Grenoble Ecole de Management, F-38000 Grenoble, France \\ 2 : GAEL UMR INRA/UPMF, 1215, F-38000 Grenoble, France \\ 3: Genostar, F-38330 Montbonnot, France \\ valerie.sabatier@grenoble-em.com, \\ adrienne.kennard@genostar.com \\ vincent.mangematin@grenoble-em.com
}

Keywords: dominant logic, business model, industry life cycle, drug industry, technological discontinuities.

\section{ABSTRACT}

An industry's dominant logic is the general scheme of value creation and capture shared by its actors. In high technology fields, technological discontinuities are not enough to disrupt an industry's dominant logic. Identifying the factors that might trigger change in that logic can help companies develop strategies to enable them to capture greater value from their innovations by disrupting that logic. Based on analyzing the changes that biotechnologies and bioinformatics have brought to the drug industry, we identify and characterize three triggers of change that can create disruptive business models. We suggest that, in mature industries experiencing strong discontinuities and high technological uncertainty, entrants' business models initially tend to fit into the industry's established dominant logic and its value chains remain unchanged. But as new technologies evolve and uncertainty decreases, disruptive business models emerge, challenging dominant industry logics and reshaping established value chains. 


\section{INTRODUCTION}

Biotechnology and bioinformatics have brought strong technological discontinuities to the traditional ways of discovering and developing drugs. Research in technology innovation and management offers multiple definitions of terms around innovation and technology management (Yanez et al., 2010). Technological discontinuities are "those rare, unpredictable innovations which advance a relevant technological frontier by an order-ofmagnitude and which involve fundamentally different product or process design"(Anderson and Tushman, 1990) but - surprisingly - those that have occurred in the drug industry seem (thus far) to have reinforced rather than challenged the positions of industry incumbents: the overall industry logics have not really changed, either in how business is done, or in how diseases are prevented or cured.

Scholars have argued that technological discontinuities lead to industry shake-outs that can nullify incumbents' competitive advantages (Hill and Rothaermel, 2003; Rothaermel, 2002; Rothaermel and Hill, 2005). An emblematic case was that of digital photography (Benner, 2002; Munir and Phillips, 2005), where the technological discontinuities disrupted the dominant logic of the entire photographic industry and led to the reshaping of its value chain. We define the value chain as "the linked set of value-creating activities all the way through from basic raw material sources for component suppliers to the ultimate end-use product delivered into the final consumer's hands" (Govindarajan and Gupta, 2001) - and in this case, its reshaping allowed new competitors to enter the industry who introduced new ways of both creating and capturing value.

Prahalad and Bettis (1986) originally defined dominant logic at the firm level as "the way in which managers conceptualize the business and make critical resource allocation 
decisions”. A dominant logic can keep organizations focused on the road ahead - or it may act as set of blinkers, restricting managers' peripheral vision (Prahalad, 2004). Dominant industry logics evolve and change over time, influencing how strategists conceive their business models and - in some cases - their company business model portfolios (Sabatier, Mangematin et al., 2010a). The evolution of dominant logics in high-tech industries has been recognized as being driven by the technologies involved (Afuah and Utterback, 1997). Industries follow general lifecycles from emergence to maturity (Agarwal and Tripsas, 2008), which are sometimes disrupted by technological discontinuities that may lead either to the industry's decline, or to a new emergent phase (Afuah and Utterback, 1997). However, the drug industry, which has been facing several waves of technological discontinuities, does not seem to be following that path when technological discontinuities occur (Allarakhia and Walsh, 2011; Galambos and Sturchio, 1998; Hopkins, Martin et al., 2007; Rothaermel, 2000), which questions the notion of drivers of evolution in technology based industries. But when technological discontinuity does not lead to disruptions of its dominant logic, what other forces lead to such change? The aim of this article is twofold: to provide an understanding of the engines that drive the evolution of industry logics, and to propose a complement to current theories (Pavitt, 1984; Tushman and Rosenkopf, 1992; Winter, 1984) by suggesting that technological discontinuities are not the only trigger for industry evolution. We argue that the convergence of business models from different industries can lead to challenges to dominant logics. While technological discontinuities can initiate industry evolution, business model innovation can also play a central role in driving change in dominant industry logics: so we examine how and why new business models emerge.

The pharmaceutical industry has experienced several waves of technological discontinuities, any of which could potentially have led to the emergence of new industry logics. This paper analyzes the triggers of the evolution of the drug industry's dominant logic 
by interviewing industry experts and analyzing the business models of new entrants. Our findings contribute to understanding the boom, bust and recovery of biotechnology and bioinformatics by following the stories of those promising technologies that encouraged stakeholders to believe in drug industry revolution. For years, entrepreneurial firms failed to deliver the expected financial and scientific performances partly because they found it difficult to fit their business models into existing dominant industry logics in profitable ways (Allarakhia and Walsh, 2011; Bosse and Alvarez, 2010; Martin, Hopkins et al., 2010). But now, by testing new business models, young entrepreneurial entrants are renewing the promise of their new technologies.

The article first explains the concepts of dominant industry logic and of business models, and provides insights (based on industry lifecycle theory) into the effects of technological discontinuities on mature industries. We then describe our data collection and analysis methods, consider the drug industry's established dominant logic, and analyze the business models of seven young bioinformatics companies. Next, we outline the triggers for change in the industry's dominant logic - new healthcare philosophies, new patterns of collaboration, and new modes of network orchestration and finally discuss our findings and the links between industry evolution and business model innovation.

\section{THEORETICAL FOUNDATIONS}

\subsection{The dominant logic of an industry}

Prahalad and Bettis have drawn on Kuhn's work on the notion of a paradigm - "a way of defining and managing the world and a basis of action in that world" (Kuhn, 1962) - to argue that managers make critical resource allocation decisions within the framework of a 'dominant logic' (Prahalad and Bettis, 1986). The authors originally developed this concept 
at the firm level, first from diversification-driven and then from environmentally-driven organizational change approaches (Bettis and Prahalad, 1995). They argue that actors evolving in the same industry develop similar mental maps of that industry, and that this dominant industry-level logic can be seen as a "mind set or a world view or conceptualization of the business and the administrative tools to accomplish goals and make decisions in that business" (Prahalad and Bettis, 1986). So the dominant logic provides a general framework within which industry firms conceive what their customers want and define how to best serve their needs, and thus - depending on what opportunities they detect - design their strategies and business models. This shared logic guides the perceptions of top managers and leaders about how best to create and capture value in the industry, and so which business models will enable their company to be profitable - but they also risk becoming overly dependent on such mental models of their competitive landscape, leading to 'cognitive inertia' (Hodgkinson, 1997). Phaal et al. (2011) identify three components of a dominant logic at the industry level: value context, value creation and value capture. The value context is the industrial landscape within which opportunities occur for creating and capturing value, and value creation refers to "the competences and capabilities used by organizations to generate products and services": the competencies have technology or knowledge-based components, while the capabilities are rooted more in processes and business routines (Marino, 1996). And value capture refers to "the mechanisms and processes used by organizations to appropriate value through delivering products and services" (Phaal et al. 2011: 223). Von Krogh et al. (2000) also suggests a strong relationship between the dominant industry logic as perceived by top managers and their firms' performance. 


\subsection{Business models}

The business model concept - a hot topic in research today (Baden-Fuller et al., 2010) comes from practitioners of the late 1990s, and is seen as distinct from strategy: "strategy refers to the choice of business models through which the firm will compete in a marketplace” (Casadesus-Masanell and Ricart, 2010). Teece (2010) argues that business models translate leaders' anticipations: “a business model reflects management's hypothesis about what customers want, how they want it, and how an enterprise can best meet those needs, and get paid for doing so". In his definition, a business model is organized around the hypothesis of what customers want, so the unit of analysis of a business model is its value proposal. Demil and Lecocq (2010) also argue that a business model refers to the articulation between different areas of a firm's activity designed to produce a value proposition for customers. In practice several different value propositions may coexist within a specific industry, each of which may dictate the use of different business models based on services or products offered by firms at different steps of the industry's value chain. The changes in managers' perceptions of their firm's opportunities will influence the continuous evolution of the business models it employs, and firms may manage a portfolio of contrasting business models to manage their risk, expected revenues and time to market more effectively (Sabatier et al., 2010a).

Industry logics and business models are closely related. Depending on how they read their industry's dominant logic, managers' mindsets will comprise their perceptions about their firm's environment and competitors (Gripsrud and Gronhaug, 1985; Hodgkinson and Wright, 2002) along with their anticipations as to their industry's future (Doz and Kosonen, 2010). These perceptions find expression in concrete leadership actions that can renew and transform both corporate strategies and business models, but discontinuities may render their 
anticipations inaccurate: their reactions to how events actually turn out may engender the emergence of new and more effective business models.

\subsection{Technological and business discontinuities}

Technological discontinuities have been identified as major triggers of change in fastevolving industries (Anand et al., 2010; Benner, 2010; Taylor and Helfat, 2009), and their effects have been well documented by such industry life cycle theorists as Klepper (1997) and Utterback and Abernathy (1975). Synthesizing contributions from technology management literature, evolutionary economics and organization ecology, Agarwal and Tripsas (2008) distinguish three stages of evolution - emergence/growth, shake out and maturity - and identify the technological changes that drive firm performance and trigger industry evolution at each stage. As industries and their technologies evolve, the mature industry stage is characterized by competition between incumbents, low firm entry and exit rates, and incremental innovations, a configuration that can allow for the profitably disintegration of value chains, allowing greater specialization of inputs and outputs that lead to improved efficiency and greater speed to market (Feldman, 2000; Herrigel, 1993; Storper, 1997; Pollock, 2011). The advent of further technological discontinuities at this stage may either speed the transition from maturity towards decline, or it may fuel a new and reinvigorating cycle, taking the industry back to an emergent stage (Afuah, Utterback and 1997; Agarwal and Tripsas, 2008; Phaal et al., 2011). At such times, when new entrants are trying to create and dominate nascent markets (Santos and Eisenhardt, 2009) incumbents must avoid resource and routine rigidities (Gilbert, 1995). Both incumbents and new entrants will be attempting to identify correctly which are the industry's most strategically valuable competencies (Gambardella and McGahan, 2010), and the value propositions that align best 
with what customers find - or will find - valuable (Agarwal and Bayus, 2002), and make their business model decisions accordingly.

While the industry life cycle literature underlines the importance of technology as a trigger for industry evolution, the drug industry presents a paradox that questions traditionally accepted theory. Biotechnology has been very innovative, often producing new versions of existing products using completely different sets of technical competencies (Walsh and Kirchhoff, 2002), discarding existing processes and requiring learning processes instead (Linton and Walsh, 2004). These technological discontinuities have been leading to the emergence of several different business models (Sabatier et al., 2010a) but did not suffice to disrupt the dominant logic of the drugs industry (Allarakhia and Walsh, 2011; Durand et al., 2008; Hopkins et al., 2007; Pisano, 2006). In other words, technological discontinuities appeared to be necessary, but not sufficient in and of themselves, to trigger disruption of the dominant logic: iit seems that other triggers are necessary to drive this change in this case. We suggest that it is only when technological (or other) discontinuities trigger business model innovations that the industry's logic evolves. Although we can observe how business models multiplied in this mature industry as it faced waves of technological discontinuities, we need to investigate what triggers might disrupt its dominant logic.

\section{THE DRUG INDUSTRY: DOMINANT LOGIC AND BUSINESS MODELS}

\subsection{Methodology}

Given our research question's focus on the disruption of dominant industry logic, we adopted a two-step research process, looking at a macro-level view of evolutionary trends via an expert study, and a micro-level view through case studies (see Figure 1). Qualitative expert studies are useful to access and understand practitioners' visions (Hansen et al., 2009), so we 
first mobilized experts to map out the evolution of the drug industry, i.e. to characterize its anticipations and trajectories. During 2008 and 2009, we interviewed twenty-two experts, with between ten and forty years' experience in the drug industry, and selected to represent the industry's diversity, including managers of pharmaceutical, biotechnology and bioinformatics companies, researchers in academic laboratories, politicians, and leaders of world competitive clusters (see list in Appendix 1). We asked them first to focus on the industry's present situation (Which businesses appear to be most profitable? How do companies interact together? What are the drivers of the industry?), and then on its historical evolution (How did new entrants insert themselves into the value chain? How did biotechnology change in the industry? What has bioinformatics changed?), and lastly to build scenarios to describe possible drug industry futures. These scenarios were drawn on a very long term perspective and focused on new technologies, alliances or networks, and value chain evolutions. Our interviews continued until we reached theoretical saturation (Eisenhardt, 1989; Glaser and Strauss, 1967), after which we completed this first data collection round with an extensive literature review on scientific, economical and managerial issues in the drug industry.

\begin{tabular}{|c|c|c|}
\hline $\begin{array}{l}\text { RESEARCH QUESTION } \\
\text { When a mature industry is } \\
\text { destabilized by } \\
\text { technological } \\
\text { discontinuities, what } \\
\text { triggers the disruption of its } \\
\text { dominant logic, and how do } \\
\text { such logics change? }\end{array}$ & $\begin{array}{l}\text { FIRST DATA } \\
\text { COLLECTION } \\
\text { Expert study and extended } \\
\text { literature review on the drug } \\
\text { industry } \\
\text { Question: what is the } \\
\text { dominant logic of the } \\
\text { industry? At the industry } \\
\text { level, what triggers for } \\
\text { industry disruption? }\end{array}$ & $\begin{array}{l}\text { SECOND DATA } \\
\text { COLLECTION } \\
\text { Seven case studies of } \\
\text { bioinformatics companies } \\
\text { Question: At the firm level, } \\
\text { how do companies } \\
\text { challenge the dominant } \\
\text { logic of the industry with } \\
\text { emerging business models? }\end{array}$ \\
\hline
\end{tabular}

Figure 1: A two-step research process

Then, in order to see how companies' emerging business models can challenge the dominant logic at the firm level, we conducted case studies of seven companies to explore 
how business models in bioinformatics, one of the more recent waves of technological discontinuities, are setting the stage for the evolution of drug industry logics. This qualitative approach is appropriate, given our aim of trying to detect and describe an emerging and contemporary phenomenon (Eisenhardt and Graebner, 2007; Santos and Eisenhardt, 2009) observing complex on-going social phenomena in a real life context can reveal how firms propose innovative business models (Eisenhardt, 1989). We studied multiple companies, representing a range of new technologies, in order to draw the most accurate conclusions: " $a$ major insight is to consider multiple cases as one would consider multiple experiments" (Yin, 2003). Our cases were chosen to reveal alternative ways of doing business outside the dominant logic, with the aim of detecting emerging patterns that contradicted existing norms. Consequently, we selected polar types (Pettigrew, 1990) that differed from the fully integrated business model, which has already been much studied, and which is associated with the dominant logic as described both by our experts and by drug industry literature (Fisken and Rutherford, 2002; Gassmann and Reepmeyer, 2005; Lane and Probert, 2007; Laroia and Krishnan, 2005; Rothman and Kraft, 2006). Searching for business model innovation, we selected seven companies that are bringing new technologies to the drug industry, and thus potentially leading to new markets (for general company characteristics, see Appendix 2). Additional criteria for inclusion were that the companies must be young (less than fifteen years old) but have been in business for at least four years, both to ensure sufficient information and to eliminate companies and business models that - while apparently novel or promising - have not yet been tested and therefore cannot be considered as representative of emerging new business models.

To understand our case companies' business models, we first interviewed each Chief Executive Officer, Chief Scientific Officer and Chief Financial Officer separately using semistructured interviews focused on their business model design as seen from the perspective of 
their functions and responsibilities, and compared these results with internal documents: annual reports, roadmaps, project descriptions etc.. Next, we collected information from scientific research journals, business journals, newspapers, trade magazines and specialist information databases to build a detailed description of each firm's business models. Following Miles and Huberman (1994), our analysis comprised three main steps: within-case analysis, data reduction and cross-case analysis. Data from each case were analyzed separately to gain a general picture of the company, its business model(s) and its evolution since inception. Each business model was then summarized in a one-page description and sent to the interviewees, and discussed and corrected where necessary. In order to identify both correspondences with, and differences from, the dominant logic, we followed Eisenhardt's recommendations (Eisenhardt, 1989; Eisenhardt and Graebner, 2007) in selecting dimensions and then looking for both within-group similarities and between-group differences.

\subsection{The drug industry's dominant logic: expert study}

Our expert panel described the industry's dominant logic as having three general characteristics: strong orientation towards product innovations; extensive use of networks and alliances; and value chain stability.

- In terms of product innovations, the pharmaceutical industry has always been based on a drug discovery > product development > commercialization path: "This business is all about finding the most promising drugs" (expert 9); "Discovery is the heart of our business" (expert 16); "Investors are generally focused on drug candidates - this is what they find valuable" (expert 22). Since its origins in the late 19th century, the industry has experienced successive waves of scientific progress, starting from the development and 
gradual acceptance of the germ theory of disease at the turn of the century, then accelerating during the chemo-therapeutic revolution of the 1930s and 1940s where pharmaceutical companies rapidly industrialized drug discovery and development and managed the entire drug value chain. In the 1940s and 1950s, progress in virology and then in microbial biochemistry and enzymology provided the basis for a new style of targeted pharmaceutical research and development (Galambos and Sturchio, 1998). The industry has focused on mass market products, and its leading and most profitable companies (Pfizer, Roche Holdings, Sanofi-Aventis, Novartis, Amgen etc.) have based their business models on integrating the three value chain activities of its traditional development path (Datamonitor, 2010). But while drug industry activities address the curative and preventive elements of treatment, the diagnostic field remains separate, from both the technological and business perspectives. The biotechnology ${ }^{1}$ and bioinformatics ${ }^{2}$ fields (which emerged in the late 1970s and early 1990s respectively) introduced new research techniques (for example, tools for rational drug design and genetic engineering) and computer programs to understand pathogenicity and disease and to generate promising potential combinations of chemical and biological drug candidates, although these are still mainly employed in the service of drug discovery.

\footnotetext{
${ }^{1}$ Scientific discoveries in life sciences led to the emergence of modern biotechnology in the late 1970s. The term 'biotechnology' embraces many different technologies: recombinant vaccines, recombinant proteins, interferon, etc.

2 Bioinformatics was born in 1990 with the advent of the Human Genome Project, which aimed to identify all the genes in human DNA, to determine the sequence of the 3 billion chemical base pairs that make it up, to store this information in databases and to develop and improve tools for analyzing the data. This advance catalyzed a drug industry race to find new drugs and led to the emergence of many bioinformatics companies. Bioinformatics provide the means of managing and analyzing floods of data using statistical methods and technology, so bioinformatics products are generally combinations of software, databases and services which enable the efficient exploitation of data to identify the key functional information to understand how genes and proteins work together in interconnected networks. Bioinformatics knowledge is applied to improve the drug discovery process, so bioinformatics are becoming an essential element in biotechnology and pharmaceutical companies' drug discovery processes. As in the biotech situation, new entrants in this field have mainly been start-ups founded by scientists from universities and laboratories (see Kennard 2009),
} 
- Networks and alliances have become much more extensively used in the drug industry since the emergence of biotechnology companies. Biotechnology has profoundly altered drug discovery heuristics and generated many new technologies for both discovery and development, bringing big technological discontinuities in terms of product and process innovation to the industry (Hopkins et al., 2007). During its emergence, most new biotech entrants were start-ups founded by scientists from universities and laboratories (Ebers and Powell, 2007) engaged in bridging upstream academic research, venture capital and large firms (Rothaermel, 2001a). Young entrepreneurial companies also tended to cluster geographically, locating themselves near to universities and other research centers $(\mathrm{Su}$ and Hung, 2009; van Geenhuizen and Reyes-Gonzalez, 2007). Alliances and partnerships became essential ways for the large companies to access young entrants' innovations, and for the innovators, in turn, to access markets (Bianchi et al., 2011; Bradfield and ElSayed, 2009; Mittra, 2007; Rothaermel, 2000). Their structures generally involved large companies positioning their smaller innovative collaborators at the start of the value chain (Rothaermel, 2001b), and such network orchestration is seen as one of the drug industry's three main activities today - "Firms need to be able to collaborate upstream and downstream, with small or large companies" (expert 17); “Networks are orchestrated by large firms that know how to manage the whole drug development" (expert 12) - and as necessary to bring together all the dispersed resources required for the whole drug discovery and development process (Powell et al., 1996; Staropoli, 1998). But even though the discovery process has been transformed by biotechnology tools and by bioinformatics, it is still typically orchestrated by the fully integrated large firms (Bosse and Alvarez, 2010; Dhanaraj and Parkhe, 2006; Sabatier et al., 2010b), whose business models have evolved so as to fully integrate their internal and external competencies, with network orchestration as a particular capability (Gassmann and Reepmeyer, 2005). 
- The stability of the value chain is strong because of the fragmentation of the innovative work, and the power of intellectual property rights and of regulations exerted by government agencies. The innovative effort can be seen as being divided between the different actors along the value chain (Arora and Gambardella, 1994; Pollock 2011), since the nature of biotechnologies' innovation processes, in particular, requires the mobilization of complementary knowledge from different disciplines, as well as of different actors' research and marketing expertise (Powell et al., 1996). The complexity of drug development and commercialization - and the fact that many of its steps can be achieved separately - has resulted in a fragmentation of the value chain that, in turn, has created opportunities for specialized companies which have developed competences, capabilities and knowledge in very specific technological and scientific drug development sectors: "Because of the complexity of the process, there are opportunities for many companies in the development of specific technologies" (expert 5); “A technological solution developed in a lab can easily become the base for the creation of a company that can become a supplier to drug developers" (expert 2). The expertise of these specialized firms is the basis of their value proposal to their customers -the large companies who continue to orchestrate overall drug development (Nosella et al., 2005; Piachaud, 2002): taken together, all these business are, effectively, part of a general processes optimization activity.

As the supposed ${ }^{3}$ cost of drug discovery, development and commercialization can exceed US\$1Bn, and take ten to fifteen years to achieve (DiMasi and Grabowski, 2007; DiMasi et al., 2003), intellectual property rights are used throughout the drug industry to protect discoveries, technologies and products (Thumm, 2004), and its keenness to defend and

\footnotetext{
3 The figures often quoted in studies for drug development costs have been questioned by, for example, Relman and Angell, 2002; and Light and Warbuton, 2011.
} 
maintain the high returns from its IP rights - even when this stance is unfavorable to the needs of developing countries - has led to much criticism of the industry (De George, 2005; McGoey et al., 2011). Recent studies report both the general stability of IP rights in the drug industry (Lilico, 2006), but also that company's policies with regard to those rights are slowly evolving (Allarakhia and Walsh, 2011).

The value chain is also highly regulated by such governmental agencies as the Food and Drug Administration in the USA and the European Medicines Agency, both of which require candidate drugs to follow strict development paths and fulfill a range of regulatory demands. These agencies seek to normalize and control the conformity of the process (Hill and Johnson, 2004; Milne, 2006) and to deliver marketing authorization at its successful conclusion: their many regulatory requirements (which have also become embedded into the broader systems of healthcare, private insurance and state regulation in developed countries) inevitably constrain the speed of drug development, and have significant cost implications for companies.

To summarize, as a general value creation and capture scheme, the dominant logic of the drug industry is product-based. Its value chain is fragmented, but highly regulated, enabling many small and medium actors to focus on process innovation and on realizing particular links in the chain. Alliances and networks are essential for drug discovery, development and commercialization, and are generally orchestrated by large companies, which hold the central position in these networks. The dominant industry logic does not favor entrepreneurial entrants' value capture opportunities, since the incumbents who are their (only) customers both control the market end of the value chain and benefit from their central positions within networks (Rothaermel and Hill, 2005; Teece, 1986). Thus, although biotechnology and bioinformatics companies create value with the new drug candidates and new technologies they bring to the chain, their returns remain low (Bradfield and El-Sayed, 
2009; Durand et al., 2008). Considering its future, Lilico argues that the highly regulated nature of the pharmaceutical industry leads to isomorphic and conservative behaviors and strategies (Lilico, 2006) which tend to reinforce its dominant logic. Rather than challenge their power and position, the technological discontinuities brought to the industry by biotechnology and bioinformatics have reinforced the hegemony of the large pharmaceutical incumbents, who have learned to integrate sufficient of the new technologies to remain at the center of their networks, and who still control market access.

\subsection{Emerging business models as a seed of industry logic evolution}

The seven case companies studied are running several business models, some of them simultaneously, of four separate types - software as a service; platform technologies; bundling; collaborative discovery - which challenge the industry's dominant logic at different levels (see Table 1 for brief descriptions).

Table 1: Brief descriptions of bioinformatics case companies' four business models

\begin{tabular}{|c|c|c|}
\hline $\begin{array}{c}\text { Business } \\
\text { Model }\end{array}$ & Description & Companies \\
\hline $\begin{array}{c}\text { Software as a } \\
\text { service }\end{array}$ & $\begin{array}{l}\text { Value proposition: Enterprise solutions, consulting services and software to } \\
\text { help with data management, sequence analysis, target identification, lead } \\
\text { identification and optimization, drug development and formulation. } \\
\text { Value capture: Fees from subscriptions to enterprise solutions and scientific } \\
\text { operating platform and for consultancy services. Possible additional revenues } \\
\text { from IP rights to software components. }\end{array}$ & $1 \& 6$ \\
\hline $\begin{array}{c}\text { Platform } \\
\text { technology }\end{array}$ & $\begin{array}{l}\text { Value proposition: Innovative software and databases to improve drug } \\
\text { discovery and development, development of new diagnostic kits, cosmetic } \\
\text { research; custom consultancy services and software and database design. } \\
\text { Value capture: Customers pay upon sale of software and database licenses and } \\
\text { analysis services. }\end{array}$ & $1,2,3 \& 4$ \\
\hline Bundling & $\begin{array}{l}\text { Value proposition: Providing a higher value software package for the customer } \\
\text { through integration of its software into complementary software offer of a } \\
\text { larger, well-established company. } \\
\text { Value capture: A percentage of the revenues from the sales of the products into } \\
\text { which its software is integrated. }\end{array}$ & 4 \\
\hline $\begin{array}{c}\text { Collaborative } \\
\text { discovery }\end{array}$ & $\begin{array}{l}\text { Value proposition: Collaboration with drug and diagnostics companies for } \\
\text { discovery of new candidates through customization of in-house platforms to } \\
\text { meet specifically defined customer goals. }\end{array}$ & $5 \& 7$ \\
\hline
\end{tabular}


These four business models have been specifically adapted in each company. Company 1 modified the software as a service business model to create more value by addressing both the drug and the agricultural biotechnology industries, while company 6 uses the same business model to address the aerospace industry and consumer products, and also allied with a large computer company to develop what the experts describe as a 'global care solution' in healthcare, again under the same value proposal.

All our sample firms deployed the platform technology business model at their inception, but their models evolved differently according to the positions they took up in their respective networks. Thus, companies 1,2,3 and 4 have tried to gain more central roles and greater control over the drug discovery and development process by offering extra value - in terms of technology and drug-candidates - and in exchange for greater rewards for their intellectual property, while company 5 already occupies a central role in a drug development network. We also noted that companies 2 and 3 use the same value proposal to address the drug and the agricultural biotechnology industries, while company 2 also employs it towards the diagnostics industry.

The bundling business model (used by company 4), contradicts the dominant industry logic in terms of how the company accesses its clients, i.e. in presenting itself as an essential partner rather than as a supplier. The company is at the center of innovation networks developing new products, and allies with large firms from the IT, diagnostics and laboratory equipment sectors.

Companies 5 and 7 use the collaborative discovery business model to ally with large diagnostics industry firms to propose innovative products, with company 5 taking a more 
central role in the architecture of its network. The partnership and joint R\&D aspects of these alliances are significant in business model innovation terms, since they require new approaches to collaboration and property rights ownership where partners, rather than addressing the mass product markets, collaborate with individual patients in designing oneoff personalized or group-specific treatments.

\section{RESULTS: TRIGGERS FOR INDUSTRY DISRUPTION}

Both our experts and the managers of the studied companies agree that, while technological discontinuities have a great impact on products and processes, they do not disrupt the dominant industry logic per se: rather they - and our business model analysis - suggest three main triggers that can change the industry logics: transformations in healthcare philosophies, new patterns of collaboration, and the collapse of the previous patterns of orchestration and integration.

\subsection{New healthcare philosophies}

Our experts often repeated their opinion that, in the long run, as new healthcare technologies emerge and converge, they will lead us to a more holistic industry. New approaches to healthcare - such as personalized medicine, nanobiotechnology, theranostics, and systems biology - are presenting physicians and hospitals with new therapeutic principles, which build new ways to address patients' needs - and so open up new business opportunities.

Personalized medicine involves analyzing the patient's unique genetic profile and molecular characteristics to enable the design of targeted patient-specific therapies, as well as the development of marker-assisted diagnosis and new modes of delivering treatment 
(Ginsburg and McCarthy, 2001). Personalized medicine promises to improve both the efficacy and safety of medical treatment for each patient: "with this kind of approach, a doctor will be able to choose the best adapted treatment, at the lowest levels of toxicity for their patients. But it requires the integration of biomolecular tests upstream in the drug development value chain" (expert 4). This approach would radically reshape the value chain and therefore the dominant industry logic: "in personalized medicine, the value is no longer in the product, but in the service" (expert 15). Remedies and services will be adapted to each patient, thus altering the current balance of treatment costs for patients, governments and private insurers, as well as of how companies capture value. This approach would also question the drug industry's traditional quest for 'block buster' drugs, and open up the possibilities of disruptive new business models.

Nanobiotechnology, defined as the applications of nanotechnologies in the life sciences (Briquet-Laugier and Ott, 2006), offers the promise of a convergent approach that could merge diagnosis, treatment and monitoring, as well as improving diagnostics and drug delivery so as to cut the quantity and toxicity of drugs injected into patients.: "Nanobiotechnology could help the development of healthcare at home: for example it could help the elderly to stay at home. We could follow their health with an implanted chip that detects physiological variations and sends messages to equipment in their room, and alarms to a team of doctors, if necessary. It could even activate the appropriate medicine automatically" (expert 6). Again, this approach is likely to create new patterns of value creation and capture, involving software ventures as well as diagnostics and drugs companies.

The theranostics approach can be defined as the use of highly specific tests for diagnosing disease, followed by the implementation of a therapeutic approach which adjusts treatment according to predicted disease development patterns. As in the previous approach, physicians' ability to monitoring their patients' responses to therapy will allow them to 
administer the most appropriate and least harmful regimen (Amir-Aslani and Mangematin, 2010). "The promises of theranostics are renewed now we made a lot of progress in diagnostics" (expert 10). Theranostics could redefine ways of choosing and delivering treatment, and thus create new business opportunities, employing models that find new ways of sharing the value captured between the companies involved in detecting and curing the disease.

The systems biology approach is quite recent and aims to describe and predict the functioning of living systems from the knowledge of their components and interrelationships, as a result of both experience and modeling (Roux and Xavier, 2007). By integrating, analyzing and combining all the information revealed by recent advances in genomic, transcriptomic and proteomic approaches, it promises to support a holistic approach to treatment: "with systems biology we can take into account the impact of a drug on the target disease but also its impact on the whole system" (expert 8). Again, this approach has the potential to create new business models which would reward, for example, companies who can use the technology to forecast the whole impact of drugs on patients.

The emerging business models, especially "software as a service" and "bundling", which build on these new healthcare philosophies, represent emerging challenges to the dominant drug industry logic. The shift from products to services transforms products into commodities, where the added value is created by the companies' ability to use bioinformatics to match treatments against patients' individual genetic profiles. As Allarakhia and Walsh (2011) suggest, solutions that involve biology, nanotechnology and computational sciences in combination question the value of the accumulated knowledge assets and their associated intellectual property which are implicit in the current paradigm. Our case studies reveal that these new healthcare philosophies - which try to promote more holistic approaches to prevention, diagnosis and therapy - are largely being implemented by small 
dedicated firms working in new types of partnership with large companies from beyond the established pharmaceutical industry. And it is this factor - the entry of incumbents from different industries - that is likely to provide a strong driver for change in the drug industry's dominant logics.

\subsection{New patterns of collaboration}

In the new shape of the drug industry implied in the previous paragraphs, new patterns of collaboration will transform the traditional balance between value creation and value capture. The switch from product to service logics will create new value capture zones, and the changes in the drug industry balance of power - as large incumbents from other sectors (diagnostics, electronics, IT, etc.) enter to explore and exploit the opportunities opened by new technologies and new healthcare philosophy visions - will challenge the domination of the large established biopharmaceutical firms. New entrants from other industries are soon going to propose new approaches to drug discovery, development and commercialization that are no longer based on the specific, complementary assets developed by the pharmaceutical industry incumbents, whose established appropriation mechanisms - and, indeed, whose whole market position and power - will be questioned. The realization of these new business models could change both how clinical trials are carried out and how these new services are commercialized, so that the capacity to manage the final drug value chain steps is no longer a complementary asset specific to incumbent pharmaceuticals. Such changes are likely to lead to the renegotiation of the comparative power of the various value-chain actors, opening up the chance for a new balance between their value creation and capture opportunities. This can already be seen operating in bioinformatics companies, who are beginning to claim more value from their innovations: thus, company 7's design of a holistic approach with its 
partners helps the innovating firms gain more royalties from the final product, and their partners less than they would have done under the previous dominant logic, but enables both to capture value from delivering the service to patients. We can already observe these disruptive new business models building on technological discontinuities to change the 'old' ways in which value has been created and captured along the value chain.

And there is another significant driver: developing and emerging countries, who need affordable drugs and treatments, are searching for alternative ways to fulfill their wants, questioning intellectual property rights policies (De George, 2005, McGoey et al., 2011), and calling for more generic drugs: "some developing countries are re-engineering drugs or vaccines in order to produce them cheaper and exempt from IP rights" (expert 13). These countries are simultaneously promoting drug and diagnostic technologies, with the result that, for example, cheap point-of-care solutions are almost on the market. "It is possible to develop a small test, for US\$0.3, which can tell you, in the middle of nowhere, if a patient has one of the 30 diseases for which you are screening. Developing countries are not the only ones to call for less costly drugs and treatments, private insurers in developed countries are also searching for ways to cut the cost of healthcare. They are starting to take interest in the drug development process, and trying to intervene upstream in its value chain" (expert 3). Such calls for new ways to prevent and cure diseases favor the emergence of new players, and production capacities are emerging worldwide, especially in India and China. The end of patent protection periods for some established drug products and the emergence of low cost generic drugs are both threatening existing pharmaceutical firms, and are being challenged from both sides: small firms that are destabilizing and redesigning the drug value chain, and large low-cost companies that are turning drugs into commodities. 


\subsection{Orchestration or Integration}

Another trigger for industry logic change revealed by our study is the emergence of new networks. Small firms (our experts also call them 'virtual companies') are beginning to coordinate whole networks to discover, develop and commercialize drugs, orchestrating parts (or even all) of the drug development and commercialization route: "small companies, with teams of five, can develop drugs from research to clinical trials" (expert 10). Given the complexity of this task, these virtual companies need strong scientific teams to lead such development: "it requires an excellent chief scientific director who understands the whole process" (expert 8). But this development of the industry logic illustrates how small firms are acquiring competence in network orchestration which, until recently, had been the sole province of large firms (Sabatier et al., 2010b; Weisenfeld et al., 2001). This trigger is also linked to a new and different vision of the future for the drug industry, one where these small virtual firms seek alliance partners other than the traditional large biopharmaceuticals, and where they create networks of SMEs which also include (maybe large) companies from outside the industry: "it is not easy, but not impossible, for a small company to orchestrate a network in which there is a large incumbent. Virtual companies can create networks of small biotech firms, but may also need to find external partners" (expert 6). In fact, it is this process - in which small firms search for new partners and new ways to do business - that is opening the door to large diversified entrants.

Table 2 sums up the main mechanisms. The case studies show that firms are challenging the dominant industry logic with new business models that are disruptive in how they ally with other players, that propose more holistic approaches to healthcare, that design 
new value chains which redistribute the value created from IP rights, that give SMEs more central roles in networks, and which help large diversified entrants enter the industry. The triggers identified by our expert commentators are already materializing in the form of new firm business models, which are summarized in the right-hand column.

Table 2: Triggers for change in dominant logic and challenging business models

\begin{tabular}{|c|c|c|}
\hline & Triggers for change in dominant logic & Challenging business models \\
\hline $\begin{array}{l}\text { New health } \\
\text { care } \\
\text { philosophies }\end{array}$ & $\begin{array}{c}\text { Personalized medicine } \\
\text { Nanobiotechnology } \\
\text { Theranostics } \\
\text { Systems biology }\end{array}$ & $\begin{array}{l}\text { New alliances with large diversified } \\
\text { companies. Shift from product to service } \\
\text { logic: drug is a commodity; service is } \\
\text { where value is captured. New value chain, } \\
\text { upsetting established one. }\end{array}$ \\
\hline $\begin{array}{l}\text { New } \\
\text { collaboration } \\
\text { patterns }\end{array}$ & $\begin{array}{l}\text { Entry of new players from other industries } \\
\text { Developing countries searching for new } \\
\text { ways to innovate, } \\
\text { Private insurances and developing } \\
\text { countries trying to lower the cost of drugs. }\end{array}$ & $\begin{array}{l}\text { Large diversified companies as new } \\
\text { entrants. } \\
\text { Redistribution of rewards of IP rights. }\end{array}$ \\
\hline $\begin{array}{l}\text { Orchestration/i } \\
\text { ntegration }\end{array}$ & $\begin{array}{l}\text { Innovation networks orchestrated by } \\
\text { virtual firms rather than large firms. }\end{array}$ & $\begin{array}{l}\text { Young entrants taking more central roles } \\
\text { in their alliances with large companies } \\
\text { from other industries. }\end{array}$ \\
\hline
\end{tabular}

The activities of these small companies show the new vision of the drug industry being 'made flesh'. Companies 5 and 6 are already involved, respectively, in theranostics and systems biology projects within alliances with actors that are external to the established industry. The proximity of bioinformatics to software technologies facilitates these new collaborative patterns, as does the convergence of their technologies (as in biochips ${ }^{4}$, for example). Recent progress in the molecular biology, genetic engineering, genomics and post genomics fields has generated a great deal of data that needs to be extracted, processed and integrated; so these alliances have not yet led to products being brought to the market, but some projects are progressing well. Other initiatives are promoting diagnostic and drug

4 Biochips can take different forms (DNA Microarray, protein chips, etc) and have in silico or in vivo applications to aid diagnosis or to release drugs in the body. Biochips require very recent technological developments from biotechnologies and bioinformatics, as well as knowledge in the science of microminiaturization from the semi-conductor industry (see for example Levine, P.M., 2009, Active CMOS biochips for electrochemical assays, PhD dissertation, Columbia University, 3388415). 
services as substitutes to existing products, which confirms the notion of emerging and converging technologies acting as triggers for new value proposals. The fact that the new industry entrants are very different from their predecessors may mark the moment-of-shift in the dominant logic. As bioinformatics companies manage the information systems that are key to value creation, they gain network centrality and their status changes from supplier to network leader, orchestrating the different participants of new value chains. Six of the seven companies we analyze are playing this kind of central role - as orchestrator and manager of network information flows - which gives them increased control over the whole product/service development, again opening up new avenues for greater value capture.

\section{DISCUSSION}

Value chain orchestration, the power of centrality and the possession of complementary assets represent different ways in which large network players used to secure value appropriation in the prior industry's dominant logic. When technological discontinuities enable change at the technological level and facilitate the entry of new players, new business models emerge which may transform the dominant logic, especially if several triggers converge.

\subsection{Discontinuities and incumbents}

Even when they are introducing breakthrough technologies, entrants entering a new industry must conform to its dominant logic at first - that is, their business models must initially fit within its established value chain and match existing client and supplier expectations, defining a recognized and specific value proposition for the industry's existing players, and thus reinforcing its dominant logic. New entrants into the drug industry have typically found business opportunities by complementing large biopharmaceuticals' needs, and by allying 
with them in networks they orchestrate. The control of complementary assets these incumbents have enjoyed hitherto has protected them against the disruption, first of biotechnology and more recently of bioinformatics companies, and they have also been able to integrate the new knowledge coming from these fields, both internally via mergers and acquisitions of biotechnology and bioinformatics companies, and externally through collaborative agreements. So established pharmaceutical firms have retained their ability to orchestrate and manage external competencies on a routine basis, including the technological discontinuities introduced by new entrants, within their existing orchestration patterns, and thus within their value chains. In other words, the disruptive nature of new technologies does not automatically change an industry's dominant logic - the challenge comes later, when business models evolve and when small firms can ally with other actors, either new or already existing, that promote a different set of complementary assets. In this case, the entry of large diversified actors from other industries has been one of the triggers of the disruption of the dominant industry logic.

When technological discontinuities are introduced into an existing industry, they confront an existing industrial organization, established market relationships, specifically developed assets, and stable and predictable collaboration patterns. Technological discontinuities do not change dominant industry logics until they begin to usher in different business models that modify asset specificities, create new dependency ties and reshape collaboration patterns, and thus change players' appropriation strategies, modifying the balance between intellectual property rights, asset specificity and bilateral collaboration. Even if a breakthrough technology is involved, as long as it can be integrated within the existing industry value chain, it will not alter the balance of power between its actors or its established appropriation modes. But when one of these components is affected, dominant industry logics may be challenged: technological discontinuities have the potential to lead to 
business model innovation and proliferation, and it is these changes that trigger the disruption of an industry's dominant logic.

\subsection{New business models as challenges to the dominant logic}

Studying other industries makes it clear that the introduction of new business models challenges dominant industry logics: for example in the music industry, the development of such technologies as high-speed broadband internet access and software has made digital content and information and its delivery increasingly ubiquitous (Wunsch-Vincent and Vickery, 2004). As long as new entrants are only small entrepreneurial firms, incumbents can maintain the dominant logic of their industries for a while, but as the technology matures and becomes widely accepted and well-diffused, new business models emerge. Low property rights will speed up this adoption and diffusion: in the music and photographic industries, dematerialization - the change from materials like CDs or negatives to digital media - and the absence or weakness of IP rights over digital contents decreased the power of rights owners, so that value capture mechanisms changed from being based (mainly) on products to being based on the services offered around the products. In the photographic industry, new digital technologies rendered all the established property rights over silver photography film and developing technologies obsolete. In the same way, progress in biotechnology and bioinformatics points towards the dematerialization of the drug industry, challenging existing dominant logics by creating opportunities for new business models to match customers' anticipations. Discontinuities which enable new technologies that disrupt dominant logics, 
create opportunities for new products and process, and thus fuel new business models.

When large diversified entrants enter (from the semiconductor industry, for example, in the case of the drug industry), dominant logics are disrupted by the arrival of business models from other industry sectors, just as the iTunes business model disrupted the music industry status quo. In the drug industry, the dominant logic created tensions at the value capture level, where recent biotechnology and bioinformatics entrants have been unable to capture as much value as they think they create: their response (deliberate or not) has been to use new technological approaches to seek a better equilibrium, in particular by allying with large diversified entrants from the IT and diagnostics industries. The switch from a product to a service logic in the drug industry promises to have a strong transformative impact on both the supply side (for both established players and new entrants) and the demand side (in offering new preventive and curative cares). By reshaping the value chain, creating new alliances and offering new value proposals, young drug industry entrants are re-negotiating how they both create and capture value. Their dissatisfaction with the established value chain patterns - which deny them the chance to capture the value they create - is contributing to the fragmentation and destruction of those chain structures, opening the door for large diversified companies from other industries to enter via alliances and partnerships.

It seems that business models innovations follow technological innovation - and when they appear (even following quite minor technological innovations, like Facebook, or Napster) they introduce new logics into the industry. When business model innovations follow major technological breakthroughs, a delay is required before the technology can be set up and specific assets and capabilities built and deployed, during which time established value chains prove adaptable enough to accommodate emerging innovative technologies. But, when actors - by themselves or via alliances - are powerful enough to promote new business models offering new value propositions and working via new value chains, the dominant 
logic is challenged, and evolves.

\section{CONCLUSION}

We can see here the beginnings of a new industry that will emerge from the upheaval of the established drug industry and its merging with the diagnostics and other industries. This observation echoes the findings of a few recent studies (Allarakhia and Walsh, 2011; AmirAslani and Mangematin, 2010; Curran et al., 2010; Linstone, 2011), which see the future of drug discovery and development in the convergence of technologies and in the trend towards personalized medicine. During the first phase after new technologies are introduced, the discontinuities they represent are not enough to induce major changes in the industry or to usher in a new logic:the industry logic remains as it was, and new ventures participate in value creation within existing value chain structures. The survival or death of incumbents is not only due to the competence-enhancing or destroying character of technological discontinuities - in fact, during this first phase, technological breakthroughs seem to have reinforced incumbents' positions in this industry. Even in the presence of major technological changes, while business models remain similar, the logic of the industry remains unchanged. But at some point a proliferation of business models emerge that challenge the dominant logic: once these supplant existing business models, new industry logics begin to form. It is business model renewal at the firm level that drives industry evolution - and alliances between entrepreneurial entrants and large external actors appear to be a key break-point in the disruption of the previous dominant logic. When technological discontinuities come from start-ups, the dominant logic of the industry evolves slowly - when they are supported by diversified entrants, we can expect faster and more radical change in dominant logics. Disrupting an industry's dominant logic involves managers creating or reinventing their 
firms' business models, and this research suggests business model evolution is likely to be progressive, a finding that is again consistent with those of other authors (Morris et al., 2005; Sosna et al., 2010), and which further enriches our understanding of the impact of business model renewal on dominant logic evolution. We suggest that managers should consider the characteristics of the dominant industry logic when proposing alternative or disruptive business models. Our findings argue that the early stages of the introduction of technological discontinuities - which are often characterized by technological uncertainty due to competition, both between new technologies and between them and existing technologies (Tushman and Rosenkopf, 1992) - are less favorable to business model innovation. Our results also indicate the conditions where existing business models could be challenged: where an industry is mature, where profitability is decreasing, where value is created by actors who cannot capture it, and where the possibility exists of allying with powerful external actors.

Analyzing the significant factors that impact competition at times of technological discontinuity allows us to propose two managerial implications. First, for incumbents, their ability to compete in nascent markets will be based on their ability to negotiate their specific complementary assets. Managers should try to detect which of these are likely to become significant as the industry evolves, and focus building competence in alliance management and on managing new networks and alliances -as necessary steps for keeping control of value capture mechanisms. Second, for new entrants, the first step is to conform to the industry's dominant logic of value creation and capture: once their technology has stabilized, they can start deploying new business models challenging one or more of its dimensions: attracting new players from other industries may help them in these disruptive efforts. Both incumbents and new entrants should consider that they must manage a double issue: complying with the existing dominant logic, but at the same time, understanding and investing in its 
transformation.

This empirical and theoretical research shows how potential alternatives to the current dominant logic have triggered and shaped our drug industry setting, showing the outlines of a potential new style of the industry, which offers alternative ways and a more holistic approach to delivering care and preventing diseases. We argue that government policies should now sustain this emerging industry, and take the opportunity to seek a better balance between patients' and business needs. 


\section{Acknowledgements:}

We acknowledge the financial support of ANR (ANR-07-NANO-026-01) and of the FP7 European project FRIDA (FP7-SSH-2007-1). The authors would like to thank the participants at COMS 2010 conference, Albuquerque, USA; and the participants of the MCOI bi-monthly seminar in Grenoble Ecole de Management, France (www.grenoble-innovation.eu), and in particular Professors Valérie Chanal, Corine Genet, Xavier Lecocq, Paul Nightingale, Philippe Very and Stephen Walsh. The authors are also very grateful to Jon Morgan of Paraphrase for his copy editing, and to the top managers of the seven bioinformatics case companies.

Usual caveats apply. 


\section{Appendix 1: List of interviewees for the expert study}

\begin{tabular}{|c|c|}
\hline $\begin{array}{c}\text { Interviewee } \\
\text { No. }\end{array}$ & Detail \\
\hline 1 & $\begin{array}{l}\text { Vice-President (in charge of European activities) for one of the largest biopharmaceutical } \\
\text { companies. }\end{array}$ \\
\hline 2 & Scientific Director in charge of scientific strategy for a world competitive cluster. \\
\hline 3 & Research Director in a National Institute of Health. \\
\hline 4 & Head of the pharmaceutical department at the French Ministry of Finance and Economics. \\
\hline 5 & Research Director in a Centre for the Study of Drug Development. \\
\hline 6 & $\begin{array}{l}\text { CEO of European Start-up, a nanomedicine company working on revolutionizing drug } \\
\text { delivery. }\end{array}$ \\
\hline 7 & $\begin{array}{l}\text { Research Director in a National Health Institute \& CEO of European Start-up (founded in } \\
\text { 2006) based on a promising technology for radio labeling, preclinical studies and } \\
\text { adiopharmaceuticals synthesis. }\end{array}$ \\
\hline 8 & $\begin{array}{l}\text { Founder and CSO of European Start-up information technology firm that provides customized } \\
\text { T solutions for drug development and patient observations }\end{array}$ \\
\hline 9 & $\begin{array}{l}\text { CEO of European biotechnology medium company proposing high value added services for } \\
\text { drug development. }\end{array}$ \\
\hline 10 & $\begin{array}{l}\text { CEO of European biotechnology medium company dedicated to the discovery and } \\
\text { development of product innovations for a specific disease. }\end{array}$ \\
\hline 11 & $\begin{array}{l}\text { CEO of European biopharmaceutical company dedicated to the development of vaccines } \\
\text { ggainst infectious diseases. }\end{array}$ \\
\hline 12 & ESO and co-founder of a European biopharmaceutical company developing drug candidates. \\
\hline 13 & ESO of European biotechnology medium company developing vaccines. \\
\hline 14 & $\begin{array}{l}\text { FOO of a European biotechnology biopharmaceutical company dedicated to product discovery } \\
\text { and development. }\end{array}$ \\
\hline 15 & CFO of European product-based biotechnology medium company. \\
\hline 16 & EFO of European biopharmaceutical company quoted on NASDAQ. \\
\hline 17 & CEO of a large worldwide bioinformatics company. \\
\hline 18 & CEO of a bioinformatics company, major actor of new generation of sequencing instruments. \\
\hline 19 & CEO of an emerging bioinformatics company. \\
\hline 20 & Research Director in an academic laboratory, using bioinformatics tools. \\
\hline 21 & Research Director in a large biopharmaceutical company, using bioinformatics tools. \\
\hline 22 & hem-informatics company. \\
\hline
\end{tabular}




\section{Appendix 2: General characteristics of the seven studied companies}

\begin{tabular}{|c|c|c|c|c|c|}
\hline $\begin{array}{l}\text { Case } \\
\text { Co. }\end{array}$ & $\begin{array}{l}\text { Year of } \\
\text { incorp'n }\end{array}$ & $\begin{array}{l}\text { Business } \\
\text { model at } \\
\text { inception }\end{array}$ & Changes between inception and 2009 & $\begin{array}{l}\text { Business } \\
\text { models in } 2009\end{array}$ & $\begin{array}{l}\text { No. of } \\
\text { employees } \\
\text { in } 2009\end{array}$ \\
\hline 1 & 1997 & $\begin{array}{l}\text { Platform } \\
\text { technology }\end{array}$ & $\begin{array}{l}\text { The first BM was based on content providing with core } \\
\text { strengths in database design. The firm subsequently } \\
\text { developed competency in software design and analytical } \\
\text { services to extend the range of its offer (2006). }\end{array}$ & $\begin{array}{l}\text { Software as a } \\
\text { service and } \\
\text { platform } \\
\text { technology }\end{array}$ & 150 \\
\hline 2 & 2004 & $\begin{array}{l}\text { Platform } \\
\text { technology }\end{array}$ & $\begin{array}{l}\text { The company was spun-off a European research } \\
\text { consortium. The company is in process of implementing } \\
\text { SaaS (end 2009). }\end{array}$ & $\begin{array}{l}\text { Platform } \\
\text { technology }\end{array}$ & 10 \\
\hline 3 & 2002 & $\begin{array}{l}\text { Platform } \\
\text { technology }\end{array}$ & $\begin{array}{l}\text { Keeping the same business model, the company is } \\
\text { adding new services to its general offer. }\end{array}$ & $\begin{array}{l}\text { Platform } \\
\text { technology }\end{array}$ & 50 \\
\hline 4 & 2000 & $\begin{array}{l}\text { Consulting } \\
\text { services }\end{array}$ & $\begin{array}{l}\text { The company changed its business model for the } \\
\text { platform technology to better focus the drug discovery } \\
\text { market (2001). The bundle business model started in } \\
2004 \text { to lower the barrier of market entry and increase } \\
\text { market penetration through commercial relationships } \\
\text { with well-established players. }\end{array}$ & $\begin{array}{l}\text { Platform } \\
\text { technology } \\
\text { and bundling }\end{array}$ & 110 \\
\hline 5 & 2000 & $\begin{array}{l}\text { Platform } \\
\text { technology }\end{array}$ & $\begin{array}{l}\text { The expertise of the company was so specific that it } \\
\text { could become a collaborative platform technology in } \\
2003 \text { and collaborative discovery platform in } 2007 \text {. }\end{array}$ & $\begin{array}{l}\text { Collaborative } \\
\text { discovery and } \\
\text { collaborative } \\
\text { platform } \\
\text { technology }\end{array}$ & 30 \\
\hline 6 & 2001 & $\begin{array}{l}\text { Platform } \\
\text { technology }\end{array}$ & $\begin{array}{l}\text { In } 2003 \text { the company changed its strategy and business } \\
\text { model, repositioning itself as a more generalist scientific } \\
\text { business intelligence company; and changed its business } \\
\text { model. }\end{array}$ & $\begin{array}{l}\text { Software as a } \\
\text { service }\end{array}$ & 450 \\
\hline 7 & 1995 & $\begin{array}{c}\text { Mix of } \\
\text { platform } \\
\text { technology } \\
\text { and software } \\
\text { as a service }\end{array}$ & $\begin{array}{l}\text { Early } 2000 \text { s the company started transitioning to the } \\
\text { hybrid business model and partnering with diagnostics } \\
\text { companies. It stopped the previous business model in } \\
2005 \text {. }\end{array}$ & $\begin{array}{l}\text { Hybrid and } \\
\text { collaborative } \\
\text { discovery }\end{array}$ & 415 \\
\hline
\end{tabular}


Afuah A.N., Utterback J.M. 1997. Responding to Structural Industry Changes: a Technological Evolution Perspective Industrial and Corporate Change 6(1): 183-202

Agarwal R., Bayus B.L. 2002. The Market Evolution and Sales Takeoff of Product Innovations. Management Science 48(8): 1024-1041

Agarwal R., Tripsas M. 2008. Technology and Industry Evolution. In S Shane (Ed.), Handbook of Technology and Innovation Management. John Wilez \& Sons

Allarakhia M., Walsh S. 2011. Managing knowledge assets under conditions of radical change: The case of the pharmaceutical industry. Technovation 31: 105-117

Amir-Aslani A., Mangematin V. 2010. The future of drug discovery and development: Shifting emphasis towards personalized medicine. Technology Analysis \& Strategic Management 77: 203-217

Anand J., Oriani R., Vassolo R.S. 2010. Alliance Activity as a Dynamic Capability in the Face of a Discontinuous Technological Change. Organization Science Forthcoming

Anderson P., Tushman M.L. 1990. Technological Discontinuities and Dominant Designs: A Cyclical Model of Technological Change. Administrative Science Quarterly 35(4): 604-633

Arora A., Gambardella A. 1994. The changing technology of technological change: general and abstract knowledge and the division of innovative labour. Research policy 23: 523-532

Baden-Fuller C., Demil B., Lecocq X. 2010. Editorial. Long Range Planning 43(2-3): 143-145

Benner M.J. 2002. Process management and technological innovation: A longitudinal study of the photography and paint industries. Administrative Science Quarterly 47(4): 676

Benner M.J. 2010. Securities Analysts and Incumbent Response to Radical Technological Change: Evidence from Digital Photography and Internet Telephony. Organization Science 21(1): 42-62

Bettis R.A., Prahalad C.K. 1995. The Dominant Logic: Retrospective and Extension. Strategic Management Journal 16(1): 5-14

Bianchi M., Cavaliere A., Chiaroni D., Frattini F., Chiesa V. 2011. Organisational modes for Open Innovation in the bio-pharmaceutical industry: An exploratory analysis. Technovation 31: 22-33

Bosse D.A., Alvarez S.A. 2010. Bargaining power in alliance governance negotiations: evidence from the biotechnology industry. Technovation 30: $367-375$

Bradfield R., El-Sayed H. 2009. Four scenarios for the future of the pharmaceutical industry. Technology Analysis \& Strategic Management 21(2): 195-212

Briquet-Laugier V., Ott M.-O. 2006. Des nanobiotechnologies à la nanomédecine du futur. BioFutur 265: $57-62$

Casadesus-Masanell R., Ricart J.E. 2010. From Strategy to Business Models onto Tactics. Long Range Planning 43(2-3)

Curran C.-S., Bröring S., Leker J. 2010. Anticipating converging industries using publicly available data. Technological Forecasting and Social Change 77: 385-395

Datamonitor. 2010. Global Pharmaceuticals, Biotechnology \& Life Sciences, Industry Profile: Reference code: 0199-2357

De George R.T. 2005. Intellectual property and pharmaceutical drugs: an ethical analysis. Business Ethics Quarterly 15(4): 549-575

Demil B., Lecocq X. 2010. Business Model Evolution: In Search of Dynamic Consistency. Long Range Planning 43(2-3) 
Dhanaraj C., Parkhe A. 2006. Orchestrating innovation networks. Academy of Management Review 31(3): 659-669

DiMasi J., Grabowski H.G. 2007. The cost of biopharmaceutical R\&D: is biotech different? Managerial and Decision Economics 28: 469-479

DiMasi J.A., Hansen R.W., Grabowski H.G. 2003. The price of innovation: new estimates of drug development cost,. Journal of Health Economics 22: 151-185

Doz Y.L., Kosonen M. 2010. Embedding Strategic Agility: A Leadership Agenda for Accelerating Business Model Renewal. Long Range Planning 43(2-3)

Durand R., Bruyaka O., Mangematin V. 2008. Do science and money go together? The case of the french biotech industry. Strategic Management Journal 29(12): 1281-1299

Ebers M., Powell W.W. 2007. Biotechnology: Its origins, organization, and outputs. Research Policy 36: $433-437$

Eisenhardt K. 1989. Building theories from case study research. Academy of Management Review 14(4): $532-550$

Eisenhardt K.M., Graebner M.E. 2007. Theory Building from Cases: Opportunities and Challenges. Academy of Management Journal 50(1): 25-32

Feldman M.S. 2000. Organizational Routines as a Source of Continuous Change. Organization Science 11(6): 611-629

Fisken J., Rutherford J. 2002. Business models and investment trends in the biotechnology industry in Europe. Journal of Commercial Biotechnology 8(3): 191-199

Galambos L., Sturchio J.L. 1998. Pharmaceutical Firms and the Transition to Biotechnology: A Study in Strategic Innovation. Business History Review 72(2)

Gambardella A., McGahan A.M. 2010. Business-Model Innovation: General Purpose Technologies and their Implications for Industry Structure. Long Range Planning 43(2-3)

Gassmann O., Reepmeyer G. 2005. Organizing Pharmaceutical Innovation: From Science-based Knowledge Creators to Drug-oriented Knowledge Brokers. Creativity and Innovation Management 14(3): 233-245

Glaser B., Strauss A. 1967. The discovery of grounded theory: Strategies of qualitative research. Wiedenfeld and Nicholson: London

Gilbert C. 1995. Undundling the structure of inertia: Resource versus routine rigidity. Academy of Management Journal 48: 741-763

Ginsburg G.S., McCarthy J.J., 2001. Personalized medicine: revolutionizing drug discovery and patient care. Trends in Biotechnology 19 (12): 491-496

Govindarajan V., Gupta A.K. 2001. Strategic innovation: a conceptual Road Map Business Horizons: 44(4) 3-12

Gripsrud G., Gronhaug K. 1985. Structure and Strategy in Grocery Retailing: a Sociometric Approach. The Journal of Industrial Economics XXXIII(3): 339-347

Hansen E.G., Grosse-Dunker F., Reichwald R. 2009. Sustainability innovation cube - a framework to evaluate sustainability-oriented innovations. International Journal of Innovation Management 13(4): $683-713$

Herrigel G. 1993. Large Firms, Small Firms and the Governance of Flexible Specialization: BadenWürttemberg and the Socialization of Risk. In Kogut B. (Ed.), Country Competitiveness: Technology and the Organizing of Work. Oxford University Press: New York 
Hill C.W.L., Rothaermel F.T. 2003. The performance of incumbent firms in the face of radical technological innovation. Academy of Management Review 28(2): 257

Hill S., Johnson K. 2004. Emerging Challenges and Opportunities in Drug Registration and Regulation in Developing Countries. DFID Health Systems Resource Center

Hodgkinson G.P. 1997. Cognitive Inertia in a Turbulent Market: the Case of UK Residential Estate Agents. Journal of Management Studies 34(6): 921-945

Hodgkinson G.P., Wright G. 2002. Confronting Strategic Inertia in a Top Management Team: Learning from Failure. Organization Studies 23(6): 947-977

Hopkins M.M., Martin P.A., Nightingale P., Kraft A., Mahdi S. 2007. The myth of biotech revolution: an assessment of technological, clinical and organisational change. Research policy 36(4): 566-589

Kennard A. 2009. Business models in the bioinformatics industry. MBA Thesis, Grenoble Graduate School of Business

Klepper S. 1997. Industry Life Cycles. Industrial and Corporate Change 6(1): 145-181

Kuhn T. 1962. The Structure of Scientific Revolutions. University Of Chicago Press

Lane C., Probert J. 2007. The external sourcing of technological knowledge by US Pharmaceutical companies: strategic goals and inter-organizational relationships. Industry and Innovation 14(1): 5-25

Laroia G., Krishnan S. 2005. Managing Drug Discovery Alliances for Success Research Technology Management 42-50

Light D.W., Warbuton R. 2011. Demythologizing the high costs of pharmaceutical research. BioSocieties 6: 34-50.

Lilico A. 2006. Six Issues in Pharmaceuticals. Institute of Economic Affairs: 33-38

Linstone H.A. 2011. Three ears of technology foresight. Technovation 31: 69-76

Linton J.D., Walsh S.T. 2004. Integrating innovation and learning curve theory: an enabler for moving nanotechnologies and other emerging process technologies into production. $R \& D$ Management $34(5)$ : $517-526$

Marino K.E. 1996. Developing consensus on firm competencies and capabilities. Academy of Management Executive 10(3): 40-51

Martin P., Hopkins M., Nightingale P. 2010. Living with 'Dinosaurs': What the case of genomics tells us about the role of New Technology Based Firms in the pharmaceutical industry. Working paper, SPRU, University of Sussex

McGoey L., Reiss J., Wahlberg A. 2011. The global health complex. BioSocieties 6: 1-9

Miles M.B., Huberman M. 1994. Qualitative Data Analysis: An Expanded Sourcebook: SAGE Publications. 2nd Revised edition

Milne C.P. 2006. US and European regulatory initiatives to improve R\&D performance. Expert Opinion on Drug Discovery 1(1): 11-14

Mittra J. 2007. Life Science Innovation and the Restructuring of the Pharmaceutical Industry: Merger, Acquisition and Strategic Alliance Behaviour of Large Firms. Technology Analysis \& Strategic Management 19(3): 279-301

Morris M., Schindehutte M., Allen J. 2005. The entrepreneur's business model: toward a unified perspective. Journal of Business Research 58: 726-735

Munir K.A., Phillips N. 2005. The birth of the 'Kodak moment': Institutional entrepreneurship and the adoption of new technologies. Organization Studies 26(11): 1665-1687 
Nosella A., Petroni G., Verbano C. 2005. Characteristics of the Italian biotechnology industry and new business models: the initial results of an empirical study. Technovation 25: 841-855

Pavitt K. 1984. Sectoral Patterns of Innovation: Toward a Taxonomy and a Theory. Research Policy 13: $343-375$

Pettigrew A.M. 1990. Longitudinal field research on change: theory and practice. Organization Science 1(3)

Phaal R., O'Sullivan E., Routley M., Ford S., Probert D. 2011. A framework for mapping industrial emergence. Technological Forecasting \& Social Change 78: 217-230

Piachaud B.S. 2002. Outsourcing in the pharmaceutical manufacturing process: an examination of the CRO experience. Technovation 22: 81-90

Pisano G. 2006. Can science be a business? Lessons from Biotech Harvard Business Review 84(10): $114-125$

Pollock A. 2011. Transforming the critique of big pharma. BioSocieties (6): 106-118.

Powell W.W., Koput K.W., Smith-Doerr L. 1996. Interorganizational collaboration and the locus of innovation. Networks of learning in biotechnology. Administrative Science Quarterly 41: 116-145

Prahalad C.K. 2004. The Blinders of Dominant Logic. Long Range Planning 37: 171-179

Prahalad C.K., Bettis R.A. 1986. The Dominant Logic: a New Linkage Between Diversity and Performance. Strategic Management Journal 7(6): 485-501

Relman A.S., Angell M. 2002. America's Other Drug Problem. The New Republic, December (16): 2741.

Rothaermel F.T. 2000. Technological Discontinuities and the Nature of Competition. Technology Analysis \& Strategic Management 12(2)

Rothaermel F.T. 2001a. Complementary assets, strategic alliances, and the incumbent's advantage: an empirical study of industry and firm effect in the biopharmaceutical industry. Research Policy 30: $1235-1251$

Rothaermel F.T. 2001b. Incumbent's advantage through exploiting complementary assets via interfirm cooperation Strategic Management Journal 22: 687-699

Rothaermel F.T. 2002. Technological discontinuities and interfirm cooperation: What determines a startup's attractiveness as alliance partner? Ieee Transactions on Engineering Management 49(4): 388

Rothaermel F.T., Hill C.W.L. 2005. Technological Discontinuities and Complementary Assets: A Longitudinal Study of Industry and Firm Performance. Organization Science 16(1): 52-70

Rothman H., Kraft A. 2006. Downstream and into deep biology: Evolving business models in 'top tier' genomics companies. Journal of Commercial Biotechnology 12(2): 86-98

Roux M., Xavier F. 2007. Biologie Systémique: standards et modèles. Omnisciences, Ecrin, Paris.

Sabatier V., Mangematin V., Rousselle T. 2010a. From Recipe to Dinner: Business Model Portfolios in the European Biopharmaceutical Industry. Long Range Planning 43(2-3)

Sabatier V., Mangematin V., Rousselle T. 2010b. Orchestrating networks in the biopharmaceutical industry: small hub firms can do it. Production Planning \& Control 21(2): 218-228

Santos F., Eisenhardt K.M. 2009. Constructing Markets and Shaping Boundaries: Entrepreneurial Power in Nascent Fields. Academy of Management Journal 52(4): 643-671

Sosna M., Trevinyo-Rodriguez R.N., Velamuri S.R. 2010. Business Model Innovation through Trialand-Error Learning. Long Range Planning 43(2-3): 383-407 
Staropoli C. 1998. Cooperation in R\&D in the pharmaceutical industry - The network as an organizational innovation governing technological innovation. Technovation 18(1): 13-23

Storper M. 1997. The regional world: Territorial development in a global economy. Guilford Press: New York

Su Y.-S., Hung L.-C. 2009. Spontaneous vs. policy-driven: The origin and evolution of the biotechnology cluster. Technovation 76: 608-619

Taylor A., Helfat C.E. 2009. Organizational Linkages for Surviving Technological Change: Complementary Assets, Middle Management, and Ambidexterity. Organization Science 20(4): 718739

Teece D.J. 1986. Profiting from technological innovation: Implications for integration, collaboration, licensing and public policy. Research Policy 15(285-305)

Teece D.J. 2010. Business Models, Business Strategy and Innovation. Long Range Planning 43(2-3): $172-174$

Thumm N. 2004. Strategic Patenting in Biotechnology. Technology Analysis \& Strategic Management 16(4): $529-538$

Tushman M.L., Rosenkopf L. 1992. Organizational Determinants of Technological Change: Toward a Sociology of Technological Evolution. Research in Organizational Behavior 14: 311-347

Utterback J.M., Abernathy W.J. 1975. A dynamic model of process and product innovation. Omega 3(6): 639-656

van Geenhuizen M., Reyes-Gonzalez L. 2007. Does a clustered location matter for high-technology companies' performance? The case of biotechnology in the Netherlands. Technological Forecasting and Social Change 74: 1681-1696

von Krogh G., Erat P., Macus M. 2000. Exploring the Link between Dominant Logic and Company Performance. Creativity and Innovation Management 9(2): 82-93

Walsh S., Kirchhoff B. 2002. Entrepreneurs' opportunities and technology based markets. In P Phan (Ed.), Technological Entrepreneurship: 17-30. IAP Press: New York

Weisenfeld U., Reeves J.C., Hunck-Meiswinkel A. 2001. Technology management and collaboration profile: virtual companies and industrial platforms in the high-tech biotechnology industries. $R \& D$ Management 31(1): 91-100

Winter S.G. 1984. Schumpeterian Competition under Alternative Technological Regimes. Journal of Economic Behavior and Organization 5: 287-320

Wunsch-Vincent S., Vickery G. 2004. Working Party on the Information Economy, Digital Broadband Content: Music. OECD Report

Yanez M., Khalil T.M., Walsh S.T. 2010. IAMOT and Education: Defining a Technology and Innovation Management (TIM) Body-of-Knowledge (BoK) for graduate education (TIM BoK). Technovation 30: 389-400

Yin R.K. 2003. Applications of Case Study Research SAGE Publications Ltd, 2nd Revised Edition 